\title{
Simple method for pretreatment of tissue sections for the detection of apoptosis by in situ end- labelling and in situ nick translation
}

\author{
S Panchalingam, G M Reynolds, D A Lammas, D C Rowlands, D S Kumararatne
}

\begin{abstract}
Aims-To overcome the problems associated with proteolytic pretreatment of tissue sections for the detection of apoptosis.

Methods-Formalin fixed, paraffin wax embedded tissue sections of reactive lymph nodes and biopsy specimens of Burkitt lymphoma were pretreated by pressure cooking for the detection of apoptosis using the in situ end-labelling and in situ nick translation methods.

Results-The results achieved with the in situ end-labelling and nick translations methods were compared with those obtained using a novel anti-apoptosis specific protein (ASP) antibody. The staining patterns generated using the three methods were similar and consistent, although the ASP antibody seemed to be more sensitive and detected higher numbers of apoptotic cells within sections.

Conclusions-Pressure cooking is advocated as an alternative method to proteolytic enzyme digestion for pretreating paraffin wax sections. It is reliable, inexpensive, reduces the need to optimise pretreatment variables for different tissues, and permits double immunostaining of sections.
\end{abstract}

(F Clin Pathol: Mol Pathol 1996;49:M273-M277)

Keywords: apoptosis, in situ end-labelling, in situ nick translation, apoptosis specific protein antibody, pressure cooker.

Apoptosis is a form of cell death which is characterised by shrinkage of the cytoplasm and condensation of the nuclear chromatin. It involves the action of endogenous endonucleases, which results in the degradation of the chromosomal DNA, to produce nuclear fragments of 200 base pairs. ${ }^{1}$ The cell subsequently breaks up into a number of apoptotic bodies containing nuclear fragments and cellular organelles, which are then phagocytosed by neighbouring macrophages. ${ }^{2}{ }^{3}$ The significance of apoptotic cell death has been reviewed extensively by Wyllie et al. ${ }^{4}$

The occurrence of apoptosis within tissues has been detected previously by a number of methods: (1) gel electrophoresis of extracted DNA $^{4}$; (2) electron microscopy ${ }^{4}$; and (3) histologically by morphological assessment. ${ }^{5}$ Each of these techniques, however, has inherent problems. Gel electrophoresis is time consuming and reflects only the sum total of the DNA status of a cell preparation. Electron microscopy requires careful preparation of samples and specialised equipment, while morphological assessment is unreliable and open to subjective interpretation. The development of in situ end-labelling ${ }^{6}$ and in situ nick translation $^{7} 8$ techniques has greatly enhanced and facilitated the detection, quantitation and distribution of apoptosis at a cellular level in both cell culture preparations and in tissue sections.

The in situ end-labelling and nick translation methods are based on the principle that endogenous endonucleases activated during apoptosis create nicks in the cellular DNA, which provides a means by which such cells can be detected. In in situ end-labelling, the $3^{\prime} \mathrm{OH}$ ends created act as sites for the incorporation of labelled nucleotide(s) (conjugated to digoxigenin or biotin) by the enzyme, terminal deoxynucleotidyl transferase (Tdt). The incorporated nucleotides can then be identified by addition of a peroxidase conjugated or fluorescein isothiocyanate (FITC) conjugated antidigoxigenin antibody or Streptavidin, respectively. FITC can be visualised directly using a fluorescence microscope, whereas peroxidase requires development by the addition of a substrate such as diaminobenzidine (DAB). With in situ nick translation, the DNA nicks are "filled in" with labelled nucleotides from the 5 'OH end, using a DNA polymerase enzyme or Klenow fragment. The nucleotides are then detected in a manner similar to that of in situ end-labelling. The action of either of these two polymerase enzymes in in situ nick translation is thought to be template dependent and thus has led to some doubt about the sensitivity of this method for the identification of apoptotic cells. $^{9-11}$

Recently, apoptosis has been implicated in the pathogenesis of a number of bacterial and viral diseases as well as malignant tumours. ${ }^{12-14}$ It has thus become imperative to confirm an in vivo role for cellular apoptosis within histological sections obtained from such conditions. One of the procedures necessary for routine histological investigation is tissue fixation, in which a $4 \%$ formaldehyde solution is used to preserve tissue morphology and in some cases also render it non-infectious. Tissue fixation in formalin, however, results in cross-linking of proteins via aldehyde groups reacting with cellular nucleophiles (for example, $\mathrm{NH} 2$ groups on amino acids or nucleic acids) to produce methylene bridges. ${ }^{15}{ }^{16}$ To reverse this cross linking and hence make the tissue amenable to molecular and immunohistochemical analysis, the sections are usually pretreated with a proteolytic enzyme such as proteinase $\mathrm{K}$. The 

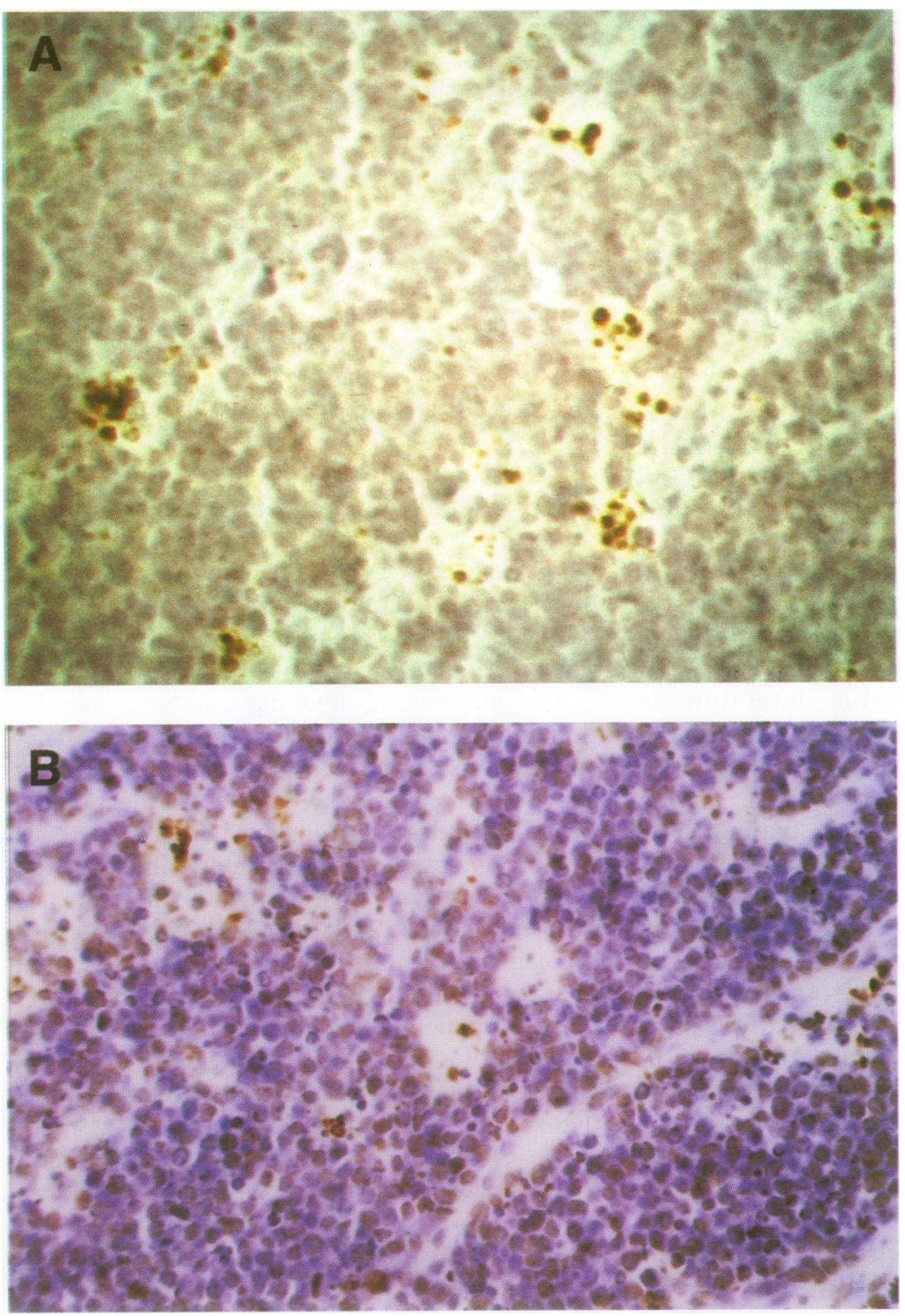

Figure 1 (A) Burkitt lymphoma section stained by in situ end-labelling (original magnification $\times 400$ ). Sections were treated with Tdt enzyme and digoxigenin labelled nucleotide and anti-digoxigenin antibody for 30 minutes. Labelled nucleotides were visualised using $D A B$. (B) Burkitt lymphoma sections stained by in situ nick translation (original magnification $\times 400$ ). Biotinylated nucleotides were detected using the tertiary antibody of the Dako ABComplex kit.

main problem encountered with this proteolytic procedure is that because of differences in tissues and in tissue fixation times, crosslinking of proteins can occur to differing degrees. As a result, enzyme concentration, digestion time and temperature, which are all critical parameters, normally have to be optimised for each tissue preparation. Moreover, further scope for differences in the final staining pattern can also occur as the decision on the "correct" treatment is very subjective. ${ }^{17}$ Furthermore, tissue digestion may sometimes destroy various surface molecules on cells, such as cluster of differentiation (CD) antigens, which may then interfere with their detection by immunostaining. A high concentration of proteolytic enzyme can also lead to false positive ${ }^{17}$ or negative detection of apoptosis, as well as to high non-specific background staining and destruction of tissue morphology. ${ }^{18}$ It has been observed previously that pro- teolytic treatment enhanced the $\mathrm{Tdt}$ reaction during in situ end-labelling, ${ }^{19}$ and that altering the degree of proteinase $\mathrm{K}$ digestion affected the results, such that prolonged digestion gave rise to non-specific staining with in situ nick translation. ${ }^{20}$

In an attempt to overcome a number of these problems, we have developed a new method of pretreating tissue sections, using pressure cooking, for the detection of apoptosis, which is simple, less time consuming and results in more consistent and enhanced staining, while not requiring complicated, expensive equipment. We have also compared the results obtained by this pretreatment method with those obtained with an antibody directed against a cytosolic apoptosis specific protein (ASP), expressed only within apoptotic cells. ${ }^{21}$

\section{Methods}

TISSUE SECTIONS

Sections ( $4 \mu \mathrm{m}$ thick) from formalin fixed, paraffin wax embedded Burkitt lymphoma and reactive lymph nodes were mounted on Superfrost charged slides (Surgipath, UK). The slides were then dewaxed and rehydrated before pretreatment.

\section{PRETREATMENT}

Two litres of a $10 \mathrm{mM}$ citrate buffer solution ( $\mathrm{pH}$ 6.0) was brought to the boil in a pressure cooker (Prestige, UK). Tissue sections were then immersed in the buffer, the pressure cooker sealed, heated for two minutes and then depressurised. The citrate buffer was subsequently washed out of the sections under running water. Endogenous peroxidase within the sections was quenched by immersing the slides in a $3 \% \mathrm{H}_{2} \mathrm{O}_{2}$ solution in methanol for $15 \mathrm{~min}$ utes and the slides were then washed in water. Positive control sections were treated with DNase I (Sigma, UK) for 15 minutes at $37^{\circ} \mathrm{C}$ prior to staining by either in situ nick translation or in situ end-labelling.

IN SITU NICK TRANSLATION

In situ nick translation was performed using a modification of the method described by Meyaard et al. ${ }^{22}$ (1) After pretreatment, sections were incubated in nick buffer $(50 \mathrm{mM}$ Tris- $\mathrm{HCl}$ ( $\mathrm{pH}$ 7.8), $5 \mathrm{mM} \mathrm{MgCl}_{2}, 1 \mathrm{M}$ $\beta$-mercaptoethanol, $10 \mu \mathrm{g} / \mathrm{ml}$ bovine serum albumin) for five minutes at $37^{\circ} \mathrm{C}$. (2) The nick translation $\operatorname{mix}(1 \mathrm{mM} / \mathrm{ml}$ dATP, dCTP, dTTP, $0.01 \mathrm{mM} / \mathrm{ml}$ biotin-16-dUTP (Boehringer Mannheim, UK) $3 \mathrm{U} / \mathrm{ml}$ DNA polymerase (Pharmacia, UK)) was then applied to the tissue sections, which were covered with parafilm and incubated for one hour at $37^{\circ} \mathrm{C}$. Negative controls were sections processed as above omitting DNA polymerase. (3) Sections were then washed in running water and loaded onto a Sequenza (Life Sciences, UK), an immunostaining system which has the advantage of minimising errors which occur within sections in manual immunostaining procedures. Two different detection systems were used: Streptavidin horse radish peroxidase (ICN Flow, UK) and the tertiary antibody of a Strept/ABC HRP duet kit (Dako, UK). The 


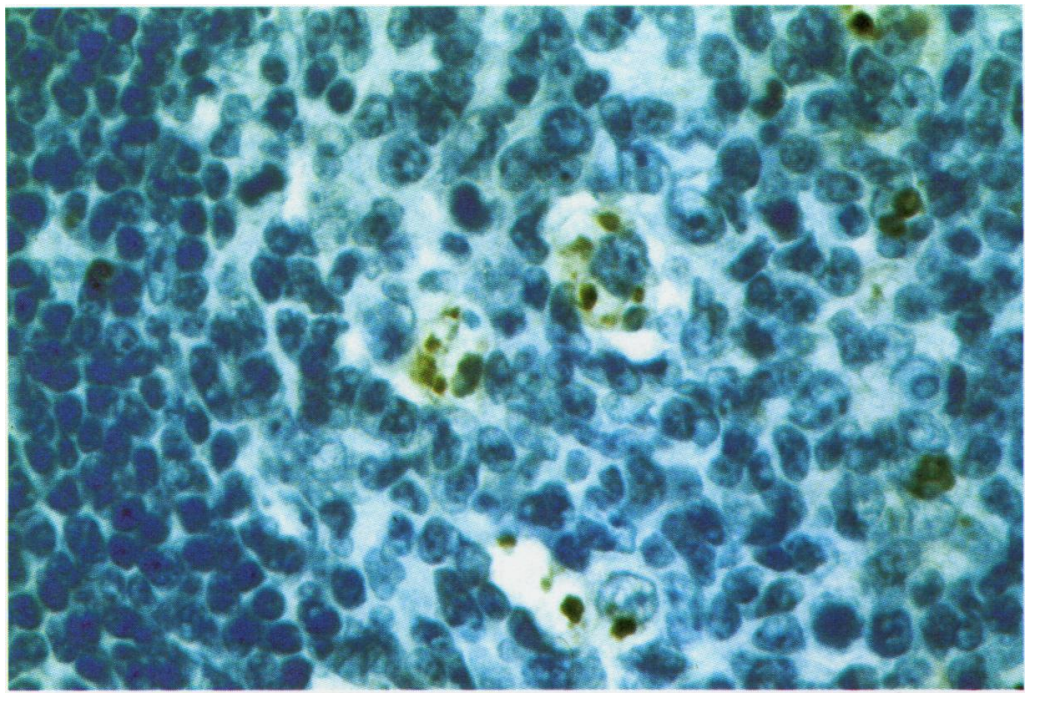

Figure 2 Germinal centre tingible body macrophages containing phagocytosed apoptotic bodies within a reactive lymph node section detected by in situ end-labelling (original magnification $\times 800$ ).

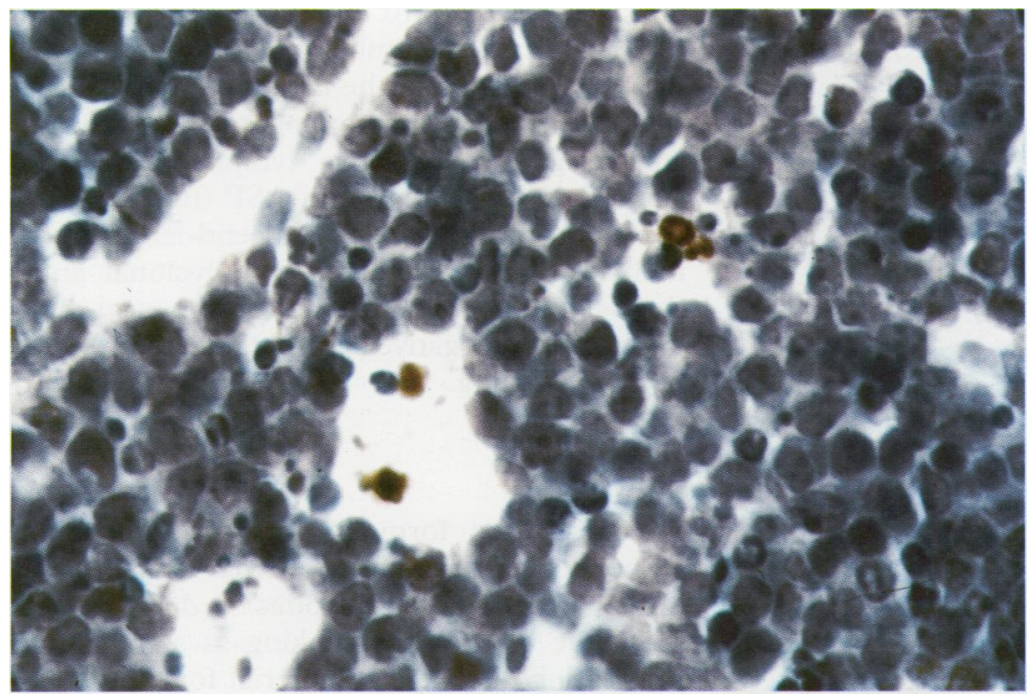

Figure 3 An apoptotic cell displaying characteristics feature of condensed nuclear material (Burkitt lymphoma section) (original magnification $\times 800$ ).

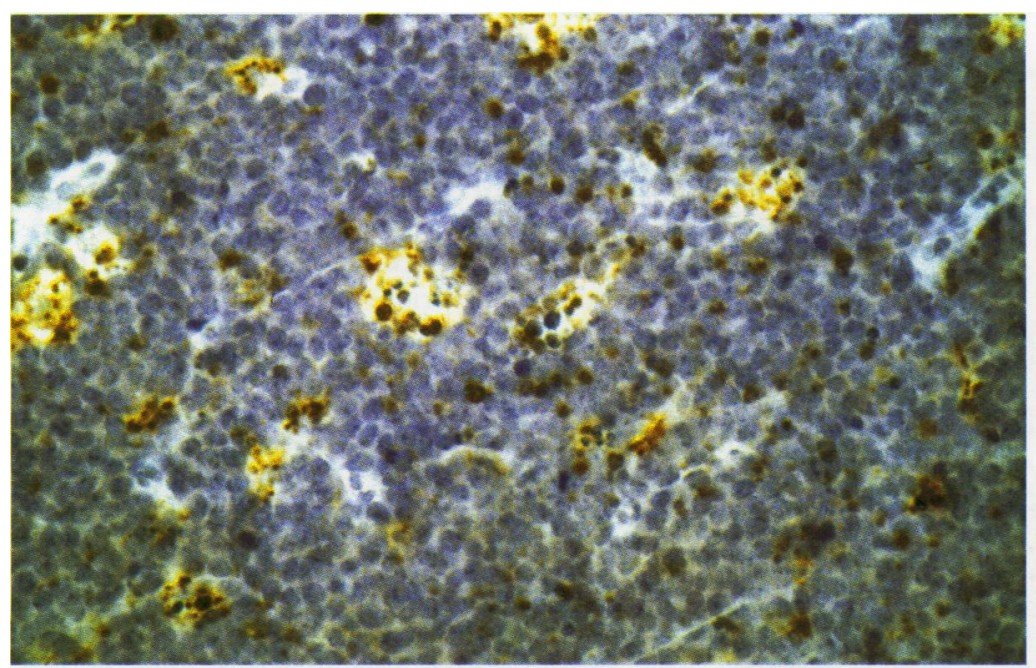

Figure 4 Burkitt lymphoma section stained by in situ end-labelling (original magnification $\times 400)$. Sections were treated omitting the Tdt enzyme as a negative control.

latter is comprised of a Streptavidin-biotin peroxidase conjugate which reacts with biotinylated antibodies or, in this case, biotinylated nucleotide. The slides were then incubated for 30 minutes with a 1 in 100 dilution of either label, washed in Tris buffered saline (TBS; $\mathrm{pH}$ 7.6), and visualised by the addition of the substrate, 3'3'-diaminobenzidine tetrahydrochloride (DAB; Sigma) for seven to 10 minutes. The sections were counterstained in Harris's haematoxylin (BDH, UK), dehydrated, cleared, and mounted.

\section{IN SITU END-LABELLING}

This was performed using the commercial in situ end-labelling Apoptag kit (Alpha Laboratories). After pretreatment, in situ endlabelling was carried out using a modification of the manufacturer's instructions as follows. (1) Sections were incubated with Tdt enzyme (omitted in the negative controls) and digoxigenin conjugated oligonucleotide(s) at $37^{\circ} \mathrm{C}$ for one hour. (2) Sections were washed in water, loaded onto the Sequenza and the peroxidase conjugated antibody applied for 30 minutes. Two antibodies were tested: that supplied in the Apoptag kit used according to the manufacturer's instructions and an antidigoxigenin peroxidase Fab fragment (Boehringer Mannheim), used at a 1 in 100 dilution. (3) Sections were then washed in TBS $(\mathrm{pH}$ 7.6) and visualised following the addition of $\mathrm{DAB}$ for seven to 10 minutes. The slides were counterstained in Harris's haematoxylin, dehydrated and mounted.

APOPTOSIS SPECIFIC PROTEIN

Pretreated sections were loaded on to the Sequenza and washed with TBS. The ASP antibody (c-jun/AP-1 (Ab-2)) a rabbit, affinity purified polyclonal antibody raised against the peptide TPTPTQFLCPKNVTD, amino acids 73 to 87 , in the $\mathrm{N}$-terminal region of v-jun (Oncogene Science, UK)) was added at a 1 in 50 dilution in $10 \%$ sheep serum for 30 minutes. A Strept ABComplex HRP Duet kit (Dako) was used for the detection of the anti-ASP antibody. Briefly, the secondary antibody (biotin goat anti-mouse/rabbit $\mathrm{Fc}$ ) was added (diluted 1 in 100) for 30 minutes, washed off with TBS ( $\mathrm{pH}$ 7.6), tertiary antibody added (diluted 1 in 100) for $30 \mathrm{~min}-$ utes, and subsequently washed off with TBS. Visualisation of the bound anti-ASP antibody was achieved by the addition of DAB for seven to 10 minutes. The slides were then washed, counterstained in Harris's haematoxylin, dehydrated, and mounted. A rabbit polyclonal antithyroglobulin antibody was used in place of the anti-ASP as a negative control.

\section{Results}

IN SITU END-LABELIING AND NICK TRANSLATION Development of the in situ end-labelling and nick translation techniques was performed on reactive lymph node and Burkitt lymphoma sections as, on conventional staining, these may contain phagocytosed apoptotic cells identifiable as "tingible body macrophages". ${ }^{23}$ Within germinal centres in both reactive lymph node and Burkitt lymphoma serial sections, in situ end-labelling and nick translation yielded similar staining patterns (fig 1), which were both consistent and reproducible. Apoptotic cells and bodies-that is, those within macro- 


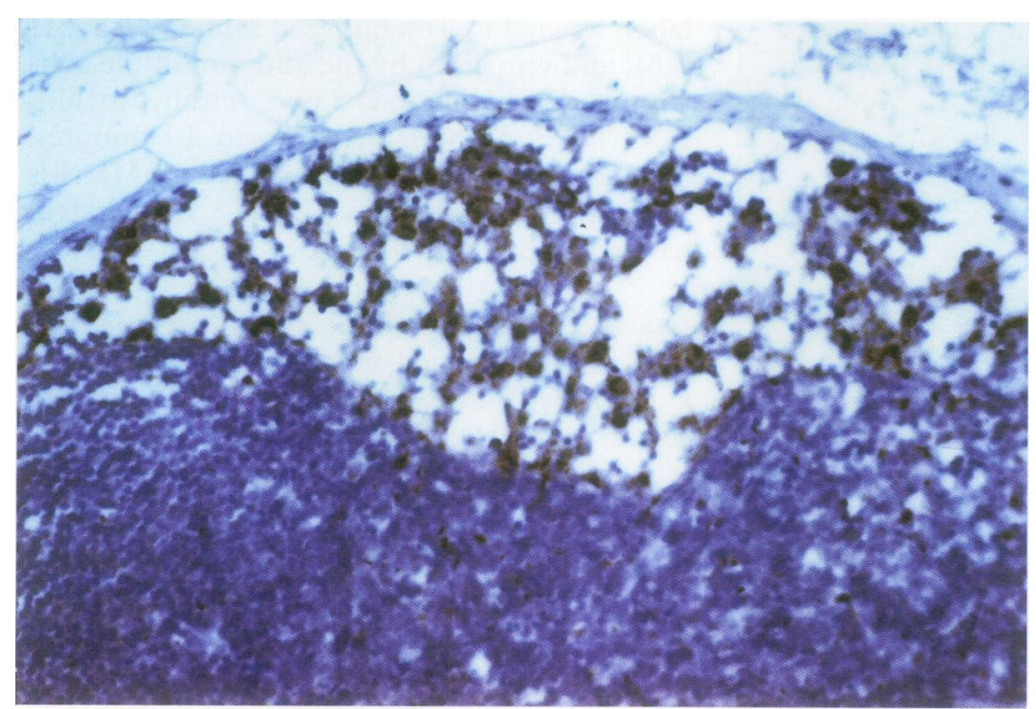

Figure 5 Positive control Burkitt lymphoma section stained by in situ end-labelling (original magnification $\times 400$ ). Sections were pre-treated with DNAase I for 15 minutes prior to addition of Tdt enzyme and digoxigenin labelled nucleotides. Labelled nucleotides were visualised using an anti-digoxigenin antibody plus $D A B$ substrate.

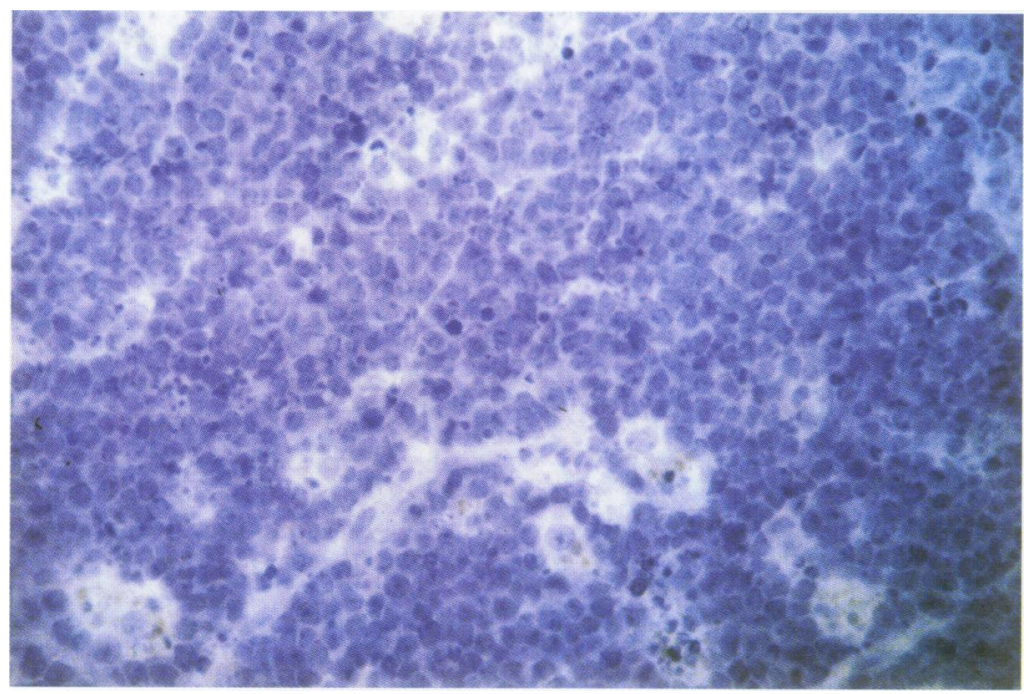

Figure 6 Burkitt lymphoma section stained with anti-ASP antibody (original magnification $\times 400$ ).

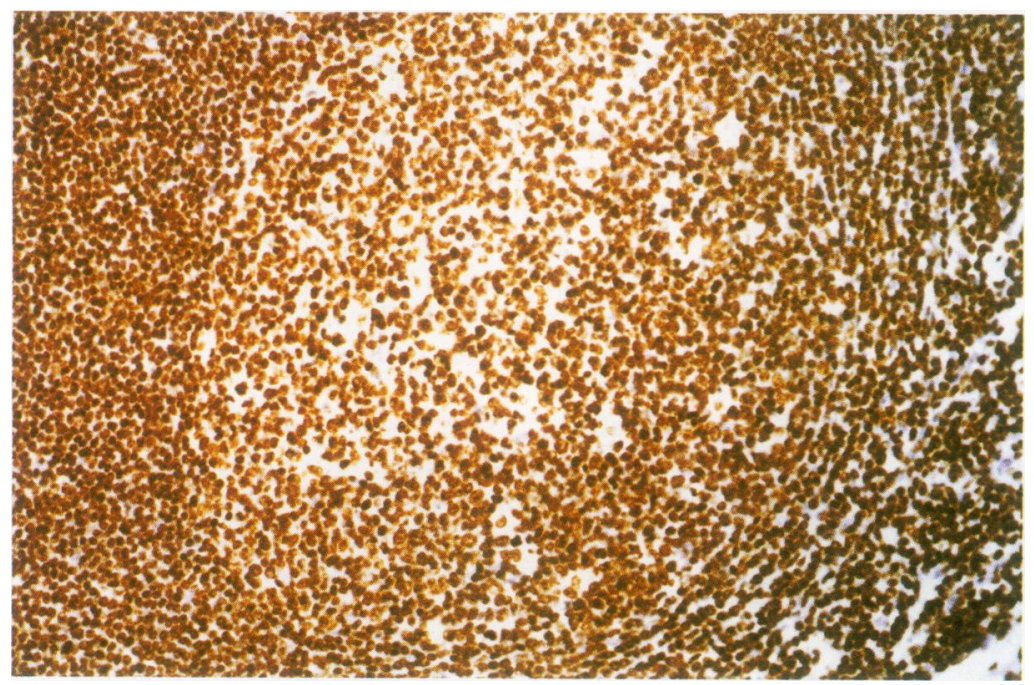

Figure 7 Macrophages in the subcapsular region of a reactive lymph node section staining positively with anti-ASP (original magnification $\times 400$ ).

phages, were detected effectively using both in situ techniques (fig 2). A number of the positively stained cells exhibited the morpho- logical features of apoptotic cells-that is, condensation of the nuclear material to the cell periphery (fig 3). Apoptotic cells were not stained in the negative control sections (fig 4). A positive control is shown in fig 5 .

The in situ nick translation technique yielded similar results using either Streptavidin horseradish peroxidase or the Dako ABC kit (results not shown). However, detection of apoptotic cells using the Dako ABC kit resulted in less background staining. This was not the case for the in situ end-labelling method (results not shown).

\section{APOPTOSIS SPECIFIC PROTEIN}

The results, in terms of cells staining positively with the anti-ASP antibody, were similar to those obtained with in situ end-labelling and nick translation in serial sections of the same node (fig 6). Cells with both fragmented and condensed nuclear material were clearly detected by all three methods (figs 1 and 6). ASP antibody seemed to be more sensitive and detected higher numbers of apoptotic cells within sections than the in situ techniques (fig 6). Furthermore, macrophages in the subcapsular region of reactive lymph nodes also stained positively with anti-ASP (fig 7), which were not detected by in situ end-labelling or nick translation. The rabbit polyclonal antithyroglobulin used instead of the anti-ASP antibody as a negative control failed to produce positive staining.

\section{Discussion}

We have used formalin fixed, paraffin wax embedded Burkitt lymphoma tissue and human reactive lymph nodes to demonstrate the value of pressure cooking as a means of pretreating histological material for the detection of apoptosis using both in situ nick translation and in situ end-labelling techniques. We have also compared the results obtained with in situ end-labelling and in situ nick translation with those obtained using a novel anti-ASP antibody, specific for a cytosolic protein expressed exclusively within apoptotic cells/ bodies. Burkitt lymphoma is a monoclonal B cell tumour and, beacuse of its histopathological features (macrophages with apoptotic bodies and cell debris ${ }^{23}$ ), was considered ideal material for the assessment of methods for the detection of apoptosis. We also assessed the three methods using reactive lymph node sections. This tissue was also regarded as good candidate material for the detection of apoptosis in view of the extensive presence of tingible body macrophages within germinal centres, reflecting the high degree of apoptosis associated with the development/selection of B cells that occurs within this structure. The in situ end-labelling and nick translation methods clearly stained apoptotic cells and bodies within macrophages in both tissue types. Similar results were obtained using the ASP antibody.

Formalin fixation results in the cross-linking of amino groups within proteins, ${ }^{16}$ rendering tissues unsuitable for immunohistochemical 
procedures. In order to overcome this problem, various methods of pretreating tissues have been put forward, principally the use of proteolytic enzyme digestion. Proteolytic pretreatment of histological specimens exposes the DNA, but renders it unsuitable as a template for polymerases because of the effect formaldehyde has on the purine and pyrimidine bases of DNA. ${ }^{24}$ Moreover, the amount of free amine available for cross-linking may vary from one tissue to another ${ }^{16}$ and as a result, the concentration of the proteolytic enzyme, temperature and length of incubation have to be carefully determined for every tissue. With pressure cooking, however, the treatment time and temperature need not be varied. Formalin fixation has been reported to cause DNA strand breaks, possibly resulting in nonspecific staining. This is unlikely to have occurred in the present study for the following reasons: (1) no random staining was observed; (2) in situ end-labelling and in situ nick translation gave similar results; and (3) the same apoptotic cells detected by in situ nick translation and end-labelling were also detected by anti-ASP antibody staining, which, unlike in situ nick translation or in situ end-labelling, is directed against a cytoplasmic protein marker of apoptosis.

In this study we have demonstrated the usefulness of a previously described anti-ASP antibody, ${ }^{21}$ for the detection of apoptotic cells within formalin fixed, paraffin wax embedded sections of two different tissues. ASP is a cytoplasmic protein that is associated with the cytoskeletal structure in cells. ${ }^{21}$ Its expression is up regulated when the apoptotic process has reached an irreversible stage and persists for long periods even when the cellular DNA is no longer detectable and therefore is a more sensitive indicator of apoptosis. ${ }^{21}$ The greater inherent sensitivity of the anti-ASP detection system may explain the ASP positive macrophages observed within the subcapsular regions of all the lymph nodes examined which were not detected by either in situ end-labelling or nick translation.

Although Lucassen et $a l^{25}$ have previously reported effective microwave pretreatment of paraffin wax sections for the detection of apoptosis via in situ end-labelling, it has been found that local superheating occurs during microwaving which results in focal points of heat, leading to non-uniform heating of the buffer. ${ }^{26}$ If a slide is then positioned away from the focal point of heat, the temperature variation leads to discrepancies in results. With pressure cooking, however, the distribution of heat is uniform. Furthermore, for the purposes of double staining - for example, dual labelling of apoptotic cells and tissue antigens, microwave and proteolytic pretreatments may not be suitable.

We have shown that pressure cooking of formalin fixed, paraffin wax embedded tissue sections before in situ nick translation and in situ end-labelling analysis is an effective, cheap and reliable method of pretreatment, allowing a large number of slides to be processed at one time. In addition, as pressure cooking is also a good method for antigen retrieval, ${ }^{26}$ this technique also allows double staining procedures to be performed. Using this method, formalin fixed, paraffin wax embedded tissues can now be examined for co-detection of both apoptosis and tissue antigens, permitting determination of the phenotype of the cells undergoing apoptosis [Panchalingam et al, manuscript in preparation].

This work was funded by the EU (grant no. T53-CT93-0254)

1 Arends MJ, Morris RG, Wyllie AH. Apoptosis: The role of the endonuclease. Am f Pathol 1990;136:593-608.

2 Kerr JFR, Wyllie AH, Currie AR. Apoptosis: a basic biological phenomenon with wide ranging implications in tissue kinetics. Br $\mathcal{f}$ Cancer 1972;26:239-57.

3 Wyllie AH. Glucocorticoid-induced thymocyte apoptosis is associated with endogenous endonuclease activation. $\mathrm{Na}$ ture 1980;284:555-6.

4 Wyllie AH, Kerr JFR, Currie A. Cell death: the significance of apoptosis. Int Rev Cytol 1980;68:251-306.

5 Rahelu M, Williams GT, Kumararatne DS, Eaton GC, Gaston JSH. Human CD4+ cytolytic T cells kill antigen pulsed target cells by induction of apoptosis. F Immunol 1993;150: 4856-66.

6 Wijsman JH, Jonker RR, Keijzer R, Van deVelde CJH, Cornelisse CJ. A new method to detect apoptosis in paraffin sections: in situ end-labelling of fragmented DNA. $¥$ Histochem Cytochem 1993;41:7-12.
chections: in situ end-labelling

7 Iseki S. DNA strand breaks in rat tissues as detected by in situ nick translation. Exp Cell Res 1986;167:311-26.

8 Fehsel K, Kolb-Bachofen V, Kolb H. Analysis of TNF- $\alpha-$ induced DNA strand breaks at the single cell level. Am $\mathcal{F}$ Pathol 1991;139:251-4

9 Gold R, Schmeid G, Giegerich G, Breitschopf H, Hartung $\mathrm{H}$, Toyka $\mathrm{K}$, et al. Differentiation between cellular apoptosis and necrosis by the combined use of in situ tailing and nick translation techniques. Lab Invest 1994;71:219-25.

10 Mundle DS, Raza A. The two in situ techniques do not differentiate between apoptosis and necrosis but rather reveal distinct patterns of DNA fragmentation in apoptosis. $L a b$ Invest 1995;72:611-12.

11 Gorczyca W, Gong J, Darzynkiewicz Z. Detection of DNA strand breaks in individual apoptotic cells by the in situ terminal deoxynucleotidyl and nick translation assays. Cancer Res 1993;53:1945-51.

12 Thompson CB. Apoptosis in the pathogenesis and treatment of disease. Science 1995;267:1456-62.

13 Chen Y, Zychlinsky A. Apoptosis induced by bacterial pathogens. Microb Pathol 1994;17:203-12.

14 Ameison JC. Programmed cell death (apoptosis) and cell survival regulation: relevance to AIDS and cancer. AIDS 1994;8:1197-213.

15 Pearse AGE. Histochemistry: theoretical and applied. Vol 1. Edinburgh: Churchill Livingstone, 1980:97-101.

16 Griffiths G. Fine structure immunocytochemistry. Berlin: Springer Verlag, 1993:36-80.

17 Hyderman E. Immunoperoxidase technique in histopathology: applications, methods and controls. $\mathcal{F}$ Clin Patho 1979;32:971-8.

18 Finley JCW, Petrusz P. The use of proteolytic enzymes for improved localisation of tissue antigens with immunocytochemistry. In: Bullock GR, Petrusz P, eds. Techniques in immunocytochemistry. Vol 1. New York: Academic Press, 1982:239.

19 Gavrieli Y, Sherman Y, Ben-Sasson SA. Identification of programmed cell death in situ via specific labelling of nuclea programmed cell death in situ via specific labelling of

20 Ansari B, Coates PJ, Greenstein BD, Hall PA. In situ end labelling detects DNA strand breaks in apoptosis and other physiological and pathological states. $\mathcal{F}$ Pathol 1993;170:1-8.

21 Grand RJA, Milner AE, Mustoe T, Johnson GD, Owen D, et al. A novel protein expressed in mammalian cells undergoing apoptosis. Exp Cell Res 1995;218:439-51.

22 Meyaard L, Otto SA, Jonker RR, Mijnster MJ, Keet RPM, et al. Programmed cell death of T cells in HIV-1 infection. Science 1992;257:217-19.

23 O'Conor GT. Malignant lymphoma in African children. II. Pathological entity. Cancer 1961;14:270-83.

24 Davison FD, Groves M, Scaravilli F. The effects of formalin fixation on the detection of apoptosis in human brain by in situ end-labelling of DNA. Histochem $\mathcal{f}$ 1995;27:983-8.

25 Lucassen PJ, Wilson CJC, Vermeulen JP, Campagne MVI Dierendock JHV, et al. Microwave-enhanced in situ end-labelling of fragmented DNA: Parametric studies in relation to postmortem delay and fixation of rat and human brain. $\mathcal{F}$ Histochem Cytochem 1995;43:1163-71.

26 Norton AJ, Jordan S, Yeomans P. Brief, high-temperature heat denaturation (pressure cooking): A simple and effective method of antigen retrieval for routinely processed tissues. F Pathol 1994;173:371-9. 